\title{
A gross anatomical and histological study of pancreas in adult Kestrel (Falco tinnunculus)
}

\author{
A.G. Al-Haaik \\ Department of Anatomy, College of Veterinary Medicine, University of Mosul, Mosul, Iraq \\ email: alhaaik_ag@yahoo.com
}

(Received March 7, 2018; Accepted May 20, 2018)

\begin{abstract}
Fifteen Kestrel were used in this study regardless to their sex. The results study showed that the pancreas of adult Kestrel (Falco tinnunculus) lies under the right side of the peritoneal cavity, and situated between the descending part and ascending part of the duodenum and has pale pinkish to white pinkish colored and consisted of 3 lobes dorsal (lobus pancreatic dorsalis), middle (middle pancreatic lobus) and ventral (lobus pancreatis ventralis) with well-developed interlobar connections made it difficult to distinguish between the 3 lobes. Histologically the pancreas of adult Kestrel (Falco tinnunculus) was covered by very thin layer of connective tissue with mesothelial cells, Connective tissue septa extended from capsule into parenchyma of pancreas dividing it in to many lobules. These septa were very thin and some of them carried blood vessels distributed all over the pancreas. The exocrine portion was constituted from serous acini with pyramidal shaped cells which had dark rounded nucleus in the middle part of the cell. Acidophilic granules found in the apices of cells. Centro acinar cells found as one or two nuclei in the center of the pancreatic acini. The endocrine portion (islets of Langerhans) was formed from clusters of endocrine cells in shape of oval or rounded pale structures with different sizes. The small one has mean diameter of $40.02 \pm 0.9 \mu \mathrm{m}$ while the large one has diameter of $126.3 \pm 3.8 \mu \mathrm{m}$. Few endocrine cells were seen distributed as single cells among the pancreatic acini.
\end{abstract}

Keywords: Pancreas, Islet of Langerhans, exocrine, endocrine Available online at http://www.vetmedmosul.com

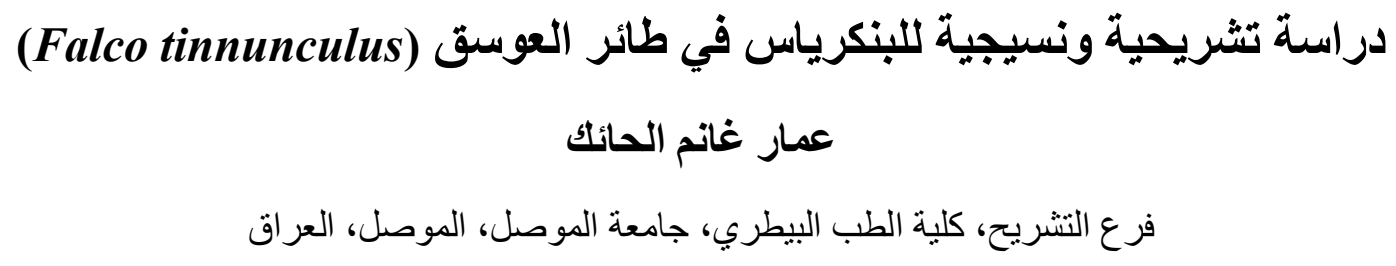

الخلاصة

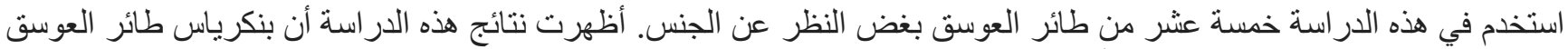

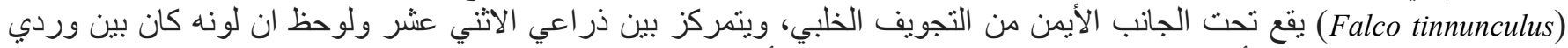

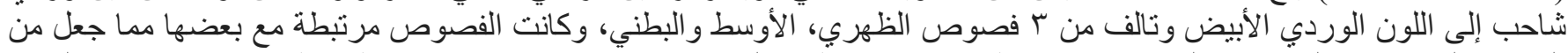

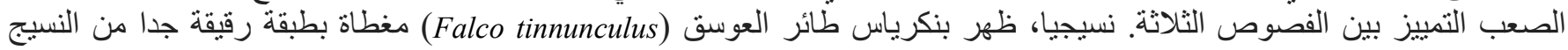

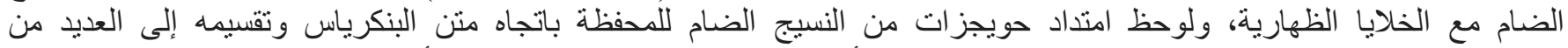

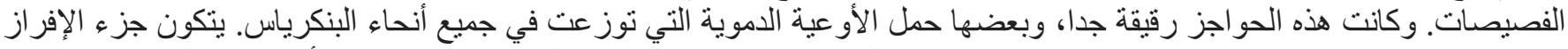

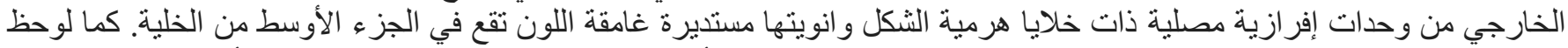

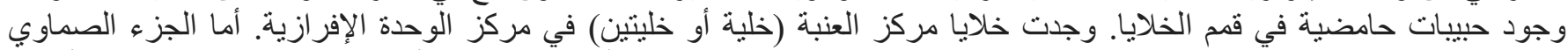

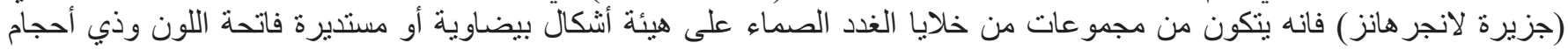

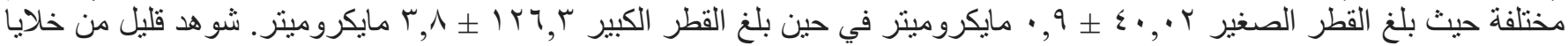
الغدد الصماء موز عة كخلايا انفر ادية بين الوحدات المصلية للبنكرياس. 


\section{Introduction}

The pancreas is large gland connected with alimentary tract (1). The location of pancreas in all birds is the right side of the abdominal cavity between the two limbs of duodenum (2). According to (3), the pancreas of the birds is considered to have four lobes: ventral, dorsal, third and splenic; with three ducts: ventral, dorsal and third, as described in chicken and quail. The avian pancreas differs from other animals in being composed of two or more lobes and in containing two islets types, there are many species differences in structure of avian pancreas, division of lobes distribution of the islets in lobes, the form and frequency of endocrine cells in islets and structure of ducts are the most important differences (4). The pancreas consists of an exocrine and endocrine portion, in such Portion the function is both carried out by some cells, the pancreas exocrine and endocrine function that are performed by different groups of cells (1). The morphologic studies of the pancreas are mainly focused on acinar and islet cells, with less attention given to the ductal epithelium. For histological properties of pancreas, and its ductal system, some investigations have been carried out in different avian species, such as the goose $(4,5)$, ostrich (6), and Coturnix quail (7). in kestrel, no information is yet available histological details of pancreas. Therefore, the present study was aimed at the demonstration of the anatomical and histological structure of the pancreas gland of the adult kestrel.

\section{Materials and methods}

A total of Fifteen healthy adult kestrel (Falco tinnunculus) were obtained from birds owner in local market (Algazal market in Baghdad) without attention to their sex (adult male or female), and then divided into 2 groups, eight for anatomical study and seven birds for histological study. The birds were killed after anesthesia by intramuscular injection of a mixture of ketamine and xylazine at dose $25.5 \mathrm{mg} / \mathrm{kg}$ of body weight (8). After that abdominal cavity was opened to explore the Shape, position and relationship of pancreas.

Then pancreas was removed and preserved in 10\% buffered neutral formalin, The pancreas were left in fixative for 48 hours then washed by tap water and dehydrated in an ascending series of graded concentration of alcohol $(70 \%$, $80 \%, 90 \%, 100 \%$ ) with a time interval of 2 hours for each stage then cleared with xylene for about 0.5 hour, infiltrated with paraffin wax for three hours and then for overnight and embedded in paraffin blocks, sections of 5 micrometers in thick were obtained by using a rotary microtome and mounted on glass slides in the presence of Mayer's albumin. Sections were stained with hematoxylin and Eosin and viewed under a light microscope (9).
The histological observation involved general description of pancreas structure in addition to several miocromorphometric parameters which achieved by using the color USB 2.0 digital image camera (Scope Image 9.0China) which was provided with image processing software.

The included parameters were: the capsule thickness, diameters of (islet of Langerhans, intralobular duct, interlobular duct, main duct), structure of islet of Langerhans, epithelium high of (intralobular duct, interlobular duct, main duct).

\section{Results}

\section{Anatomical finding}

The pancreas of kestrel (falco tinniculus) is a short, semi-wide, lobulated gland that located under the right side of the peritoneal cavity, and situated between the descending part and ascending part of the duodenum and has pale pinkish to white pinkish colored (Figure 1).

It consisted of 3 lobes, dorsal (lobus pancreatic dorsalis), middle (middle pancreatic lobus) and ventral (lobus pancreatis ventralis) and well developed interlobar connections made it difficult to distinguish between the 3 lobes.

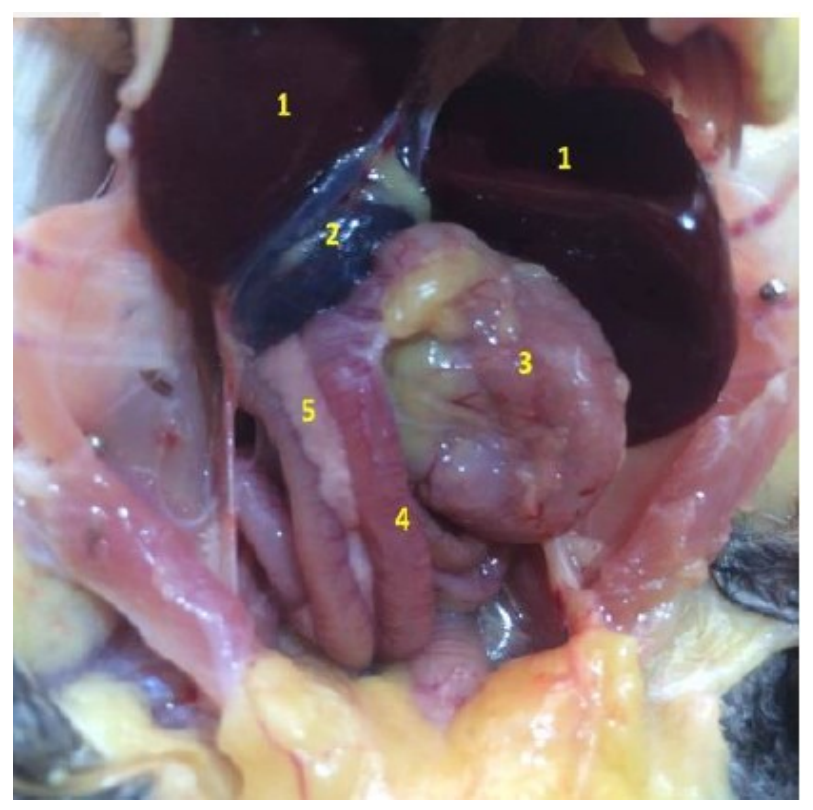

Figure 1: Microphotograph illustrate, liver (1), gall bladder (2), gizzard (3), duodenum (4), pancreas (5).

The pancreas is attached tightly by mesentery and blood vessels positioned between the between the descending part and ascending part of the duodenum which composed of two main lobes, dorsal and ventral lobes, that appeared 
extend from the origin of duodenal loop to one third length of the duodenal loop and another small lobe originated from the end of dorsal lobe towards the spleen. The lobes of pancreas were very short and not full the space between the two limbs of duodenum so, there was a gap between the duodenal limbs. In the current study the ventral lobe is thicker than the dorsal lobe and has a duodenal impression on either side of dorsal surface (Figure 2).

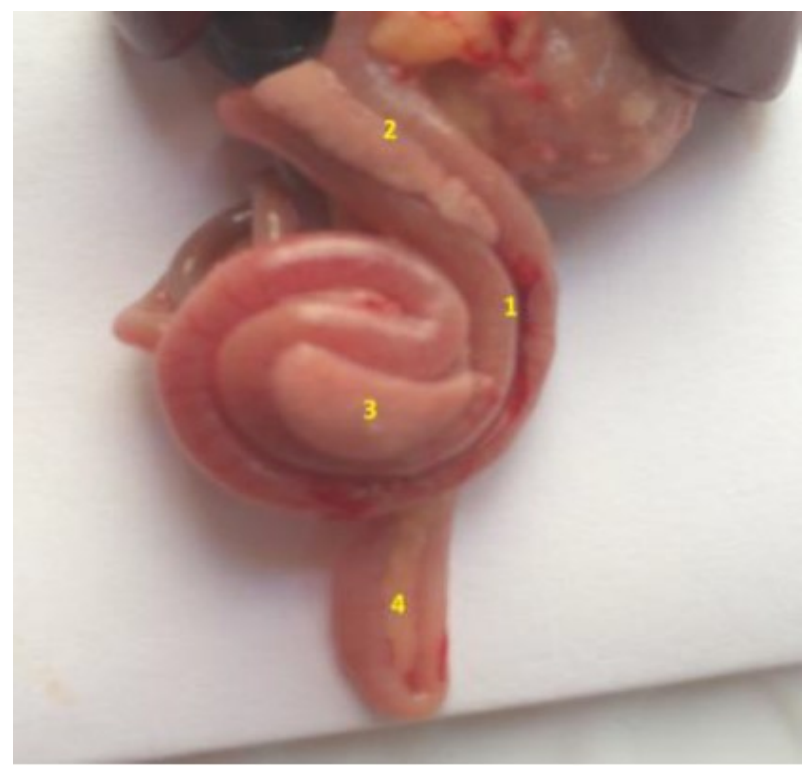

Figure 2: Microphotograph illustrate, duodenum (1), dorsal part (2), middle part (3), ventral part (4).

\section{Histological finding}

The microscopic investigation of the pancreas in kestrel showed that it covered by very thin layer of connective tissue with mesothelial cells, the mean thickness of capsule was $11.71 \pm 0.2$ (Figure 3, Table 1). The connective tissue septa extended from capsule into parenchyma of pancreas dividing it in to many lobules. These septa were very thin and some of them carried blood vessels distributed all over the pancreas. Blood vessels were varied in their sizes and ganglionic nerve cells found in perivascular connective tissue of large blood vessels and characterized by oval or rounded pale nuclei with prominent nucleolus (Figure 4). The parenchyma of pancreas in kestrel was composed mainly from exocrine portion represented by serous acini and endocrine portion which distributed among acini which represented by islets of Langerhans (Figure 5).

The exocrine portion was constituted from serous acini with pyramidal shaped cells which had dark rounded nucleus in the middle part of the cell. Acidophilic granules found in the apices of cells. Centro acinar cells found as one or two nuclei in the center of the pancreatic acini (Figure 6).
Table 1: micro morphometric parameters of different pancreas structures / $\mu \mathrm{m}($ mean $\pm \mathrm{SE})$

\begin{tabular}{lcc}
\hline Parameters & $\mu \mathrm{m}$ \\
\hline Islet of Langerhans diameter & small & $40.02 \pm 0.9$ \\
Intralobular duct diameter & large & $126.03 \pm 3.8$ \\
Interlobular duct diameter & $74.21 \pm 2.9$ \\
Main duct diameter & $108.31 \pm 4.3$ \\
Capsule thickness & $566.60 \pm 13.7$ \\
Intralobular duct epith. Height & $11.71 \pm 0.2$ \\
Intralobular duct epith. Height & $16.82 \pm 0.89$ \\
Main duct epith. Height & $17.71 \pm 0.7$ \\
\hline
\end{tabular}

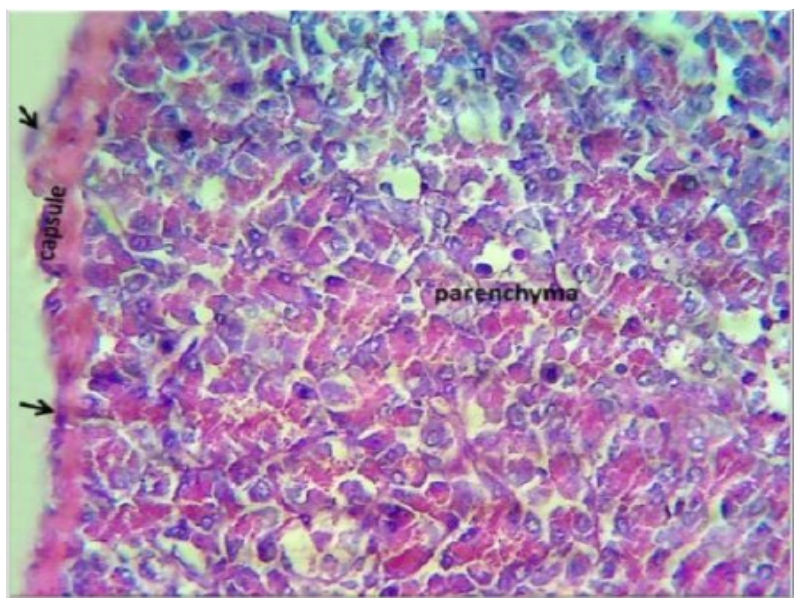

Figure 3: Microphotograph illustrate, the parenchyma of pancreas covered by a thin layer of connective tissue capsule with mesothelial cells (arrows). H\&E, X400.

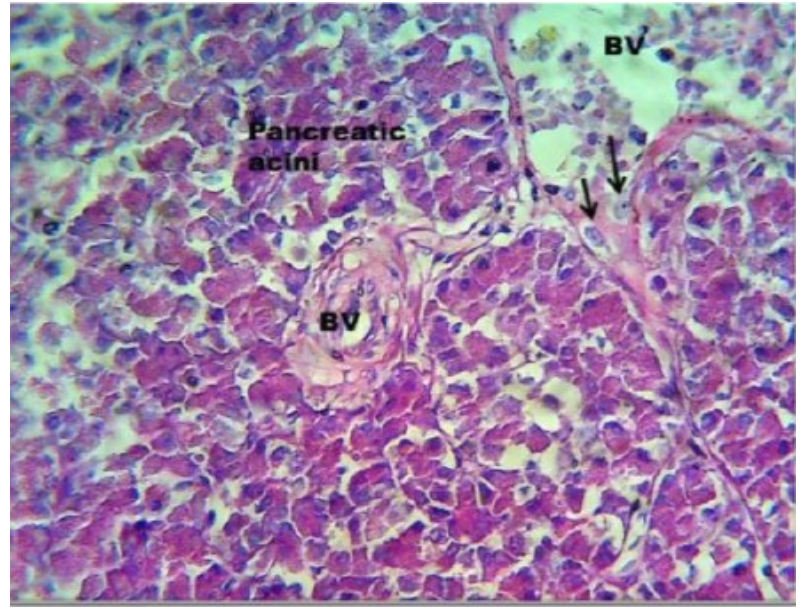

Figure 4: Microphotograph illustrate, the blood vessels (BV) among pancreatic acini. Note the ganglionic nerve cells (arrows) within the connective tissue around blood vessel. H\&E, X400. 


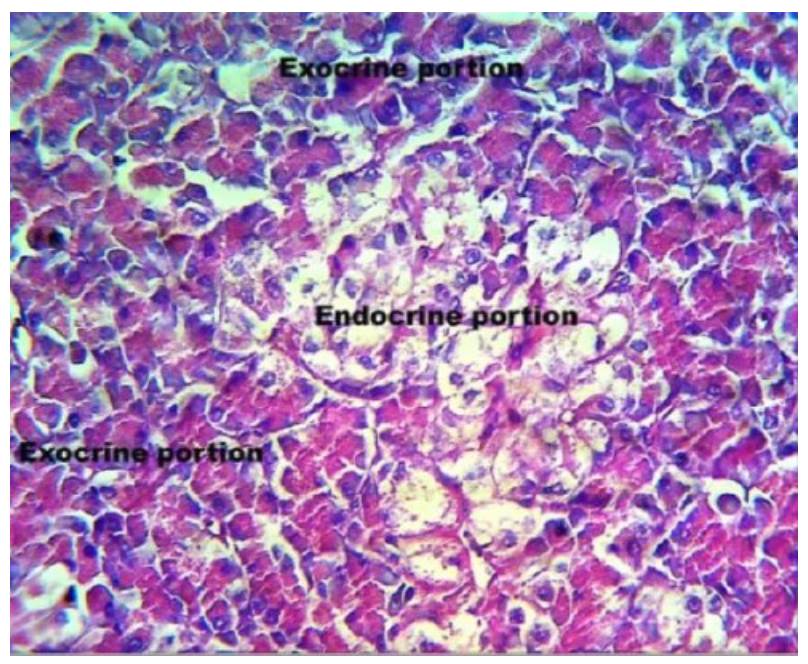

Figure 5: Microphotograph illustrate, the endocrine and exocrine portions of pancreas. H\&E, X400.

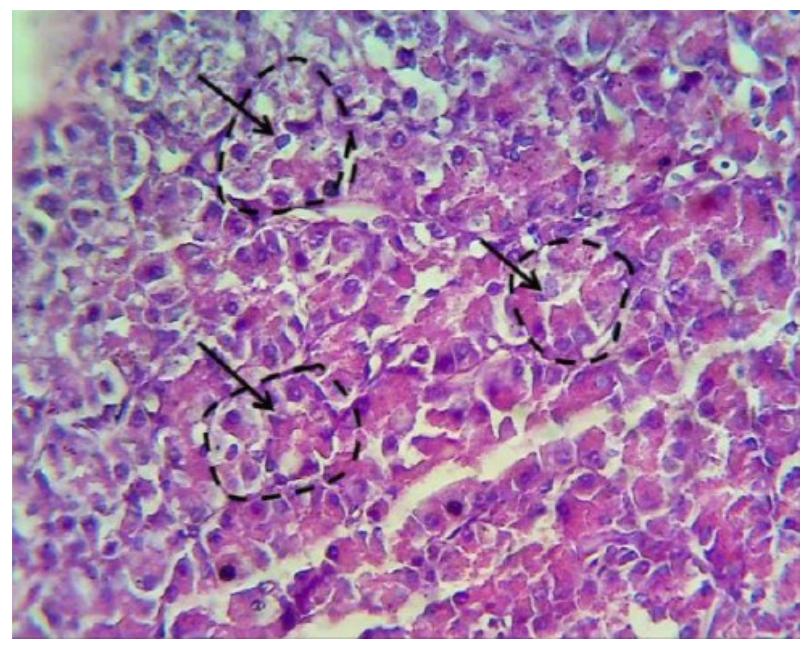

Figure 6: Microphotograph illustrate, the pancreatic acini (dotted circles) and the centro acinar cells (arrows)in the center of acini. H\&E, X400.

The duct system of the exocrine portion of kestrel pancreas was consisting of intralobular duct; inter lobular duct and main duct. The intercalated duct was absent. Intralobular duct appeared among the pancreatic acini and lined by simple cuboidal to low columnar cells with rounded nuclei. The mean diameter was $74.21 \pm 2.9$ and the height if its epithelium was $16.82 \pm 0.89$. Scanty connective tissue fibers were found surrounding these ducts (Figure 7). Interlobular duct was situated in the connective tissue among pancreatic lobules. The mean diameter was $108.31 \pm 4.3$ and lined by simple columnar to low columnar epithelium with height of $17.7 \pm 0.7$. Abundant connective tissue was surrounding these ducts (Figure 8).

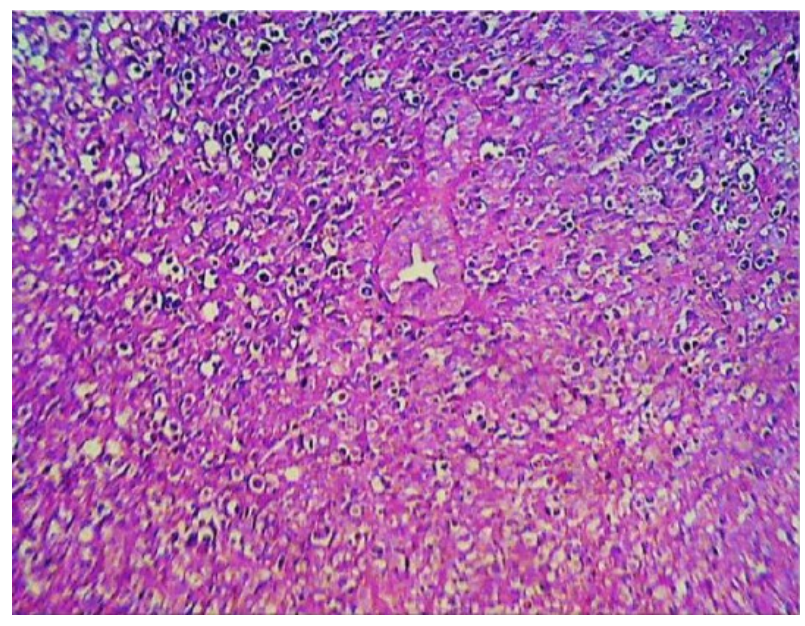

Figure 7: Microphotograph illustrate, the intralobular duct within pancreatic lobule. H\&E, X100.

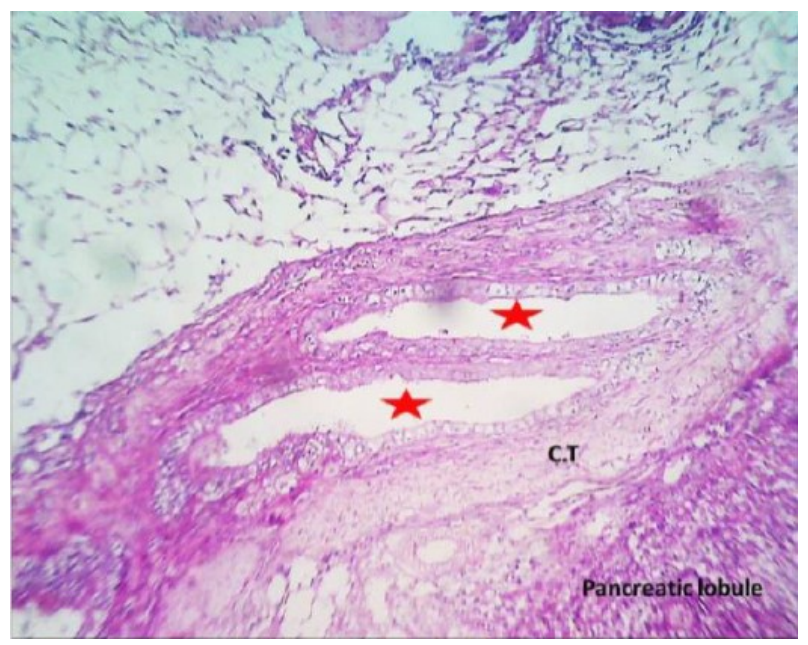

Figure 8: Microphotograph illustrate, the interlobular duct (red star) in the connective tissue (CT)between pancreatic lobules. H\&E, X 100.

The main pancreatic duct appeared with large diameter $566.6 \pm 13.7$ and lined by stratified columnar epithelium with height of $37.46 \pm 0.9$. Longitudinal folds were found in its mucosa, its wall consist of thick layer of connective tissue mixed with smooth muscle, this duct found surrounded by adipose tissue (Figure 9). The endocrine portion (Islets of Langerhans) was formed from clusters of endocrine cells in shape of oval or rounded pale structures with different sizes. The small one has mean diameter of $40.02 \pm 0.9$ while the large one has diameter of $126.3 \pm 3.8$. Few endocrine cells were seen distributed as single cells among the pancreatic acini. Two type of cells found in these islets, alpha cells which appeared fewer in number with small pale nuclei and beta cells which appeared more 
numerous with large dark nuclei. Small blood vessels were distributed among the endocrine cells (Figure 10).

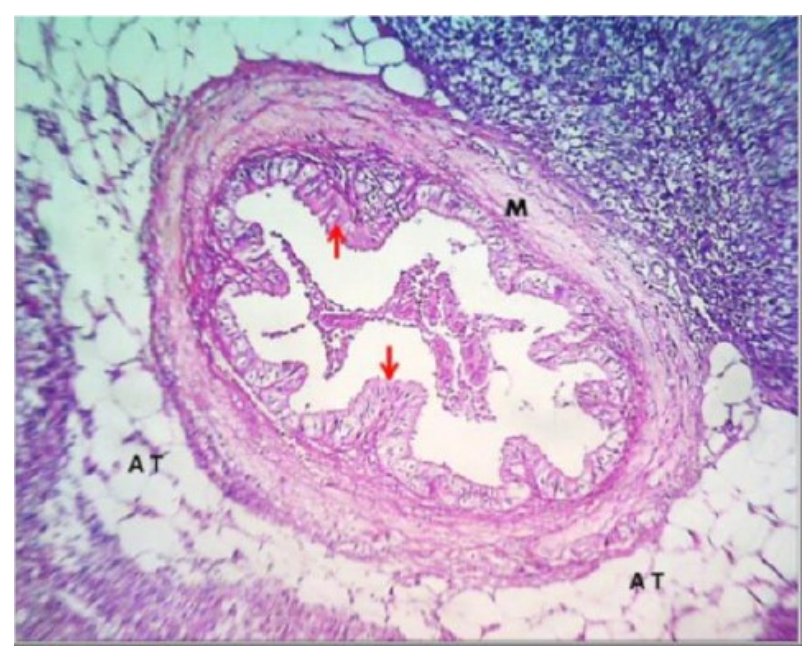

Figure 9: Microphotograph illustrates the main pancreatic duct. Note the longitudinal folds in its mucosa lined by pseudostratified columnar epithelium (red arrows), note thick muscular wall of the duct (M), and the surrounding adipose tissue (AT). H\&E, X 100.

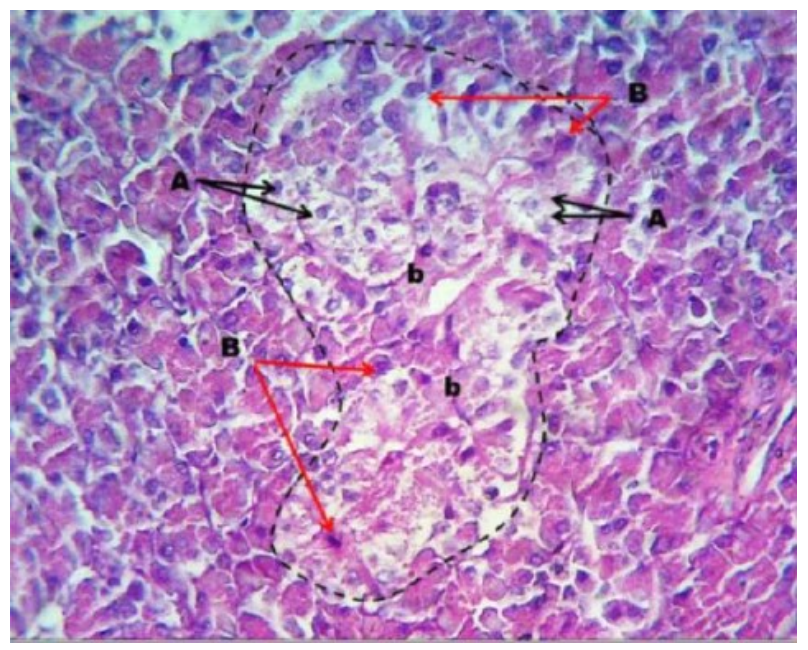

Figure 10: Microphotograph illustrate, island of Langerhans (dotted line) contain (A) alpha cells (B.) Beta cells and (b) blood vessles ac acinar cells. H\&E, X40.

\section{Discussion}

This result disagrees Bailey et al. (10) in captive bustards whom they found that the pancreas was a paleyellow organ with a finely lobulated surface situated between 2 limbs of the duodenum and it was frequently hidden by fat. It consisted of 2 lobes lying dorsally (lobus pancreatic dorsalis), and ventrally (lobus pancreatic ventralis) and well developed interlobar connections made it difficult to distinguish between the 2 lobes in most of the birds examined.

These results disagree with Gulmez et al. (4) in Goose, who said that the ventral lobe is divided into the ventral lobe proper and the third lobe on the basis of the latter's independent form. However, (11) reported in their research that the pancreas of ducks has two lobes, the dorsal lobe is divided into three distinct segments or sub lobes.

This coincides McClish and Eglitis (11) on the pancreas of indigenous ducks that the ventral lobe is thickest one and has a duodenal impression at its both sides of the dorsal surface but disagree Al-Shaeli (12) that the pancreas consists of four lobes and the dorsal lobe is longer than the ventral, splenic and accessory lobe. On the other hand, (13) noted that the mynah pancreas had no splenic lobe, but many other birds as duck, chicken and goose have four lobes and splenic segment is attached to the dorsal lobe while the third lobe in mynah, as in chicken was a part of the ventral lobe (14).

The microscopic investigation of the pancreas in kestrel showed that it covered by very thin layer of connective tissue with mesothelial cells. this result is in agreement AlSudany (15) on the pancreatic capsule in steppe buzzard and rock dove and (5) Aughey and Frye (16) in goose but in contrast, the capsule of pancreas was thick in the turkeys (17).

The connective tissue septa extended from capsule into parenchyma of pancreas dividing it in to many lobules. These septa were very thin and some of them carried blood vessels distributed all over the pancreas, which is similar to previous findings by Dellmann (18).

Blood vessels were varied in their sizes and ganglionic nerve cells found in perivascular connective tissue of large blood vessels and characterized by oval or rounded pale nuclei with prominent nucleolus, this finding was in concords with the findings of (19) in duck , (17)in turkey, and (20) in chicken .

The parenchyma of pancreas in kestrel was composed mainly from exocrine portion represented by serous acini and endocrine portion which distribute $\mathrm{d}$ among acini which represented by islets of Langerhans, this result which again concords with the findings of Das et al. (19) in duck, Gulmez et al. (4) in goose, and Mobini (17) in turkey.

The exocrine portion was constituted from serous acini with pyramidal shaped cells which had dark rounded nucleus in the middle part of the cell. Acidophilic granules found in the apices of cells. Centro acinar cells found as one or two nuclei in the center of the pancreatic acini, this result enhanced by Al-Agele and Mohammed (21) in goose who found that the bizonal character of acinar cells could be attributed to the presence of mitochondria and zymogen granules in basal and apical portion and showed the 
cytoplasm with acidophilic zymogenic granules and small centroacinar cells without granules were projected in the lumen of the acinus..

The duct system of the exocrine portion of kestrel pancreas was consisting of intralobular duct; inter lobular duct and main duct. The intercalated duct was absent. This result was in disagreement with Al-Agele (21) when described the epithelium lining of the intercalated ducts and intralobuler ducts were surrounded by connective tissue fibers with few elastic fibers. In addition to this, the smooth muscle fibers were surrounding both the main pancreatic duct and interlobular ducts.

Interlobular duct appeared among the pancreatic acini and lined by simple cuboidal to low columnar cells with rounded nuclei. Scanty connective tissue fibers were found surrounding these ducts. Interlobular duct was situated in the connective tissue among pancreatic lobules. and lined by simple columnar to low columnar epithelium Abundant connective tissue was surrounding these ducts. The main pancreatic duct lined by stratified columnar epithelium, Longitudinal folds were found in its mucosa, its wall consist of thick layer of connective tissue mixed with smooth muscle these findings were in agreement with many other researchers such as Simsek and Alabay (22) in quail, Al-Shaeli (12) in duck $(16,23)$. Two type of cells found in Islets of Langerhans, alpha cells which appeared fewer in number with small pale nuclei and beta cells which appeared more numerous with large dark nuclei. This results disagreement with many other researchers (12) in duck (24) and (25) whom they showed that there are three different types of islets have been observed in birds. but it was in agreement with (21) in golden eagle.

\section{Reference}

1. Gussekloo SWS. Feeding structures in birds. $1^{\text {st }}$ ed. Combridge: Wallingford; 2006. 201-205.

2. Sturkie PD. Avian Physiology. $4^{\text {th }}$ ed. New York: Springer Verlag; 1986. 498.

3. Baumel JJ. Handbook of Avian Anatomy: Nomina Anatomica Avium. $2^{\text {nd }}$ ed. Cambridge: Nuttall Ornithological Club; 1993. 544.

4. Gulmez N, Kocamis H, Aslan S, Nazl M. Immunohistochemical distribution of cells containing Insulin, Glucagon and somatostatin in the Goose (Anser anser) pancreas. Turk Anim Sci. 2003;28:403-407.

5. Mobini B. Histological studies on pancreas of Goose (Anser Albifrons). Vet Res. 2011;2:25-29.

6. Stornelli MR, Ricciardi M P, Miragliotta V, Coli A. Giannessi E. Morpho-structural study of the pancreas and pancreatic duct in ostrich
(Struthio camelus). Acta Vet Brno. 2006;75:157-160. DOI: $10.2754 / \mathrm{avb200675020157}$

7. Smith PH. Pancreatic islets of the coturnix quail: A light and electron microscopic study with special reference to the islet organ of the splenic lobe. Anat Rec. 1974:178:567-585.

8. Shindala MK. Anaesthetic effect of ketamine and ketamine with diazepam in chicken. Iraq J Vet Sci. 1999;12:261-265.

9. Suvarna SK, Christopher L, Bancroft JD. Theory and practice of histological technique. $3^{\text {rd }}$ ed. New York: Churchill Livingstone; 2013. 109-121 p.

10. Bailey TA, Mensha BE, Samour J, Naldo J, Lawrence P, Garner A. Comparative morphology of the alimentary tract and its glandular derivatives of captive bustards. J Anal. 1997;191:398.

11. McClish RD, Eglitis JA. Distribution of the A and B cells and of the islet Langerhans in duck pancreas. Ohio J Sci. 1969;69:285-293.

12. Al-Shaeli SJ. Anatomical and histological study of pancreas in local breed ducks (Anas platyrhnchos, Mallard) [MSc thesis]. Baghdad: College of Veterinary Medicine, University of Baghdad; 2010:44-47.

13. Saadatfar Z, Asadian M. Anatomy of pancreas in Mynah (Acrido theres tristis). J Appl Anim Res. 2009;36:191-193. DOI: $10.1080 / 09712119.2009 .9707057$.

14. Tarakcy BG, Yaman M, Bayrakdar A. Immunohistochemical study on the endocrine cells in the pancreas of the ostrich (Struthio camelus). J Anim Vet Advan. 2007;6:693-696.

15. Al-Sudany AA. Comparative anatomical study of pancreas in some birds [MSc thesis]. Al-Qadisiya: University of Al-Qadisiya; 2007: 3951.

16. Aughey E, Frye FL. Comparative veterinary histology with clinical correlates. $1^{\text {st }}$ ed. London: Manson Publishing Ltd; 2001. 240-242 p.

17. Mobini B , Aghaabedi B. Histological and histochemical studies on pancreas of native turkey in Iran. Vet J. Pajouhesh Sazandegi. 2009; $22(83): 2-8$.

18. Dellmann HD. Textbook of veterinary histology. $4^{\text {th }}$ ed. New York: Lea and Febiger; 1993. 190-191 p.

19. Das A, Das RK, Parida S. Histomorphological study on pancreas of duck (Anas boscas). Indian J Anim Sci. 2003;73(6):598-599.

20. Ohmori Y, Wakita T, Watanabe T, Auton J. Sympathetic and sensory neurons projecting into the cervical sympathetic trunk in the chicken. J Auton Nerv Syst. 1992;40(3):207-13p

21. Al-Agele RAA, Mohammed FS. Architecture morphology and histological investigations of pancreas in Golden Eagles (Aquila Chrysaetos). Al-Anbar J Vet Sci. 2013;5(2):149-155.

22. Simsek N, Alabay B. Light and electron microscopic examinations of the pancreas in quails (Coturnix coturnix japonica). Revue Med Vet. 2008;159:198-206.

23. Liu JW, Evans H, Larsen P. Pan DX, Dong HC, Deng XB, Wan BG. Gross anatomy of the pancreatic lobes and ducts in six breeds of domestic ducks and six species of wild ducks in china. Anat Histol Embryol. 1998;27:413- 417.

24. Steiner DJ, Abraham K, Miller K, Hara M. Pancreatic islet plasticity: Inter species comparison of islet architecture and composition of islets. Bio Sci J. 2010;2(3):135-145.

25. Kadhim KK, Zuki AB, Noordin MM, Babjee SM, Zamri SM. Morphological study of pancreatic duct in red Jungle fowl. Afri J Bio. 2010;9:7209-7215. 